J. Product. \& Dev., 22(3): 683-696 (2017)

\title{
BEHVIOUR OF PRIME SEEDLESS GRAPEVINES GROWN UNDER SANDY SOIL CONDITIONS TO FOLIAR APPLICATION OF CHITOSAN
}

Esraa, M. E. Hussein

*Hort. Department,. Faculty of Agriculture, Aswan Univ., Egypt.

\begin{abstract}
This study was undertaken three times during 2015 and 2016 seasons to test the effect of spraying chitosan at 50 to 800 ppm three times on vegetative growth, vine nutritional status, berry setting \%, yield, shot berries \% and berries quality of prime seedless grapevines grown under sandy soil condition.

Carrying out three sprays of chitosan at 50 to $800 \mathrm{ppm}$ had an obvious promotion on all vegetative growth aspects chlorophylls a \& $b$, total carotenoids, $N, P, K$ and $M g$ in the leaves, berry setting \%, cluster weight, vine yield and berries quality relative to the control. A remarkable reduction on the percentage of shot berries was recorded with using chitosan treatments.

Conclusively, the best results with regard to yield and berries quality of Prime seedless grapevines grown under sandy soil condition were obtained due to treating the vines thrice with chitosan at 200 ppm.
\end{abstract}

Keywords: Chitosan, Prime seedless grapevines, yield, berries quality

\section{INTRODUCTION}

Many attempts were accompanied for alleviating the adverse effect of soil and water salinity as well as drought on yield and berries quality of grapevine cvs grown under sandy saline soil. Therefore, the idea of using chitosan as a promising and new natural compound for overcoming of these problems was raised. Chitosan is considered a biopolymer produced from chitin and is very safe for human being. It has bioactivity and biocompatibility (Dias et al., 2013). Using it in plants resulted in improving the yield and reducing transpiration (Dzung et al., 2011 and Mondal et al., 2012). It is an important antioxidant and using it was accompanied with blocking relative oxygen species (ROS) and protecting the vines from their damages (Parl et al., 2004). It is responsible for enhancing the tolerance of plants to bacterial, viral and fungal attack (Al-Hetar et al., 2011). The plants subjected to chitosan are less prone to all biotic and abiotic stresses 
(Lizarraga-Pauli et al., 2011; Jabeen and Ahmad, 2013 and Pongprayoon et al., 2013). It enhances vital processes and changing expression of genes (Limpanavech et al., 2008; Hadwiger, 2013 and Nguyen-Van et al., 2013). It stimulated plant reacting and the impact on microorganisms and the molecular weight seems to be one of the most essential factors affecting the biological activity of this material (Kulikov et al., 2006; Aranaz et al., 2009 and Li et al., 2011).

Previous studies emphasized the essential role of chitosan on stimulating growth aspects, as well as, improving yield and quality parameters of fruits (Chibv and Shibayamia, 1999; Li and Yu, 2000; Bittelle et al., 2001 and Devlieghere et al., 2004). The results of experiments confirmed the beneficial effects of using chitosan on both physical and chemical characteristics of the fruits (Imeri and Knoor, 1988; GasenMetithanis, 1996; Siripatrawan and Harte, 2010; Corradinin et al., 2010; Ghasemneznad et al., 2010; Abdel-Mawgoud et al., 2010; Abd Jabbar and Miamaj, 2012; Salachna and Zawadzinska, 2014; Plainsirichai et al., 2015).

The merit of this study was throw some lights on the effects of chitosan on growth, vine nutritional status, yield as well as physical and chemical characteristics of the berries of Prime seedless grapes vines grown under Sandy soil condition.

\section{MATERIALS AND METHODS}

This study was conducted during 2015 and 2016 seasons on thirty-six uniform in vigour 5-years old Prime seedless grapevines. The chosen vines are grown in private vineyard located at West Souhag, Souhag district, Souhag Governorate when the texture of the soil is sandy (Table 1). Soil analysis was done according to the procedures that outlined by Cottenie et al., (1982). The selected vines are planted at 2 X 3 meters a part. Spur pruning system using Gable supporting method was followed. At the first week of Jan. during both seasons, pruning was carried out leaving 72 eyes (on the basis of leaving 20 fruiting spurs each with three eyes plus six replacement spurs $\mathrm{X}$ two eyes). The vines were irrigated via deip irrigation system $(\mathrm{EC}=1000 \mathrm{ppm})$.

The selected vines (36) received all the regular horticultural practices that are commonly applied in the vineyard.

This study contained the following six treatments from different concentrations of chitosan: 
Table 1: Analysis of the vineyard soil.

\begin{tabular}{|l|c|}
\hline Constitute & Values \\
\hline Sand \% & 81.9 \\
\hline Silt \% & 8.1 \\
\hline Clay \% & 10.0 \\
\hline Texture & Sandy \\
\hline pH $(1: 2.5$ extract) & 7.99 \\
\hline E.C $(1: 2.5$ extract, ppm) & 940 \\
\hline CaCO $\%$ & 4.1 \\
\hline O.M \% & 0.15 \\
\hline Total N \% & 0.009 \\
\hline Available P $(\mathrm{ppm})$ & 1.92 \\
\hline Available K (ppm) & 41.3 \\
\hline
\end{tabular}

1- Control (water sprayed vines)

2- Spraying chitosan at $50 \mathrm{ppm}$.

3- Spraying chitosan at $100 \mathrm{ppm}$.

4- Spraying chitosan at $200 \mathrm{ppm}$.

5- Spraying chitosan at $400 \mathrm{ppm}$.

6- Spraying chitosan at $800 \mathrm{ppm}$.

Each treatment was replicated three times, two vines per each. Chitosan was sprayed three times on vine canopy at growth start $\left(1^{\text {st }}\right.$ week of Mar.) and at three week intervals ( $1^{\text {st }}$ week of Mar. and $3^{\text {rd }}$ week of Apr.). Chitosan at the assigned amounts was dissolved in few drops of $0.1 \mathrm{~N}$ $\mathrm{NaOH}$ for facilitating the solubility. Triton is a wetting agent was added at $0.1 \%$ to all solution spraying of chitosan and spraying was done till runoff. Randomized complete block design (RCBD) was followed.

During both seasons, the following measurements were conducted:

1- Vegetative growth aspects namely; main shoot length $(\mathrm{cm})$, number of leaves/shoot, leaf area $\left(\mathrm{cm}^{2}\right)$ (Ahmed and Morsy, 1999); wood ripening coefficient (Bouard, 1966) were all determined in the middle of May. In addition, pruning wood weight $(\mathrm{kg}) / \mathrm{vine}$ and cane thickness $(\mathrm{mm})$ were determined in the middle of January.

2- Chlorophylls $a$ and $b$, total carotenoids (as mg/100g F.W) after extraction by acetone(Hiscox and Isralstam, 1979).

3- Percentages of N, P, K and Mgin the petioles of leaves located opposite to the basal clusters, on dry weight basis (Cottenie et al., 1982 and Balo et al., 1988). 
4- Berry setting\%, yield expressed in weight $(\mathrm{kg})$ and number of cluster/vine as well as cluster weight and percentage of shot berries (determined by dividing the number of small berries by the total number of berries per cluster and multiplying the product by 100).

5- Physical and chemical characteristics of the berries namely berry weight (g) and dimensions (longitudinal and equatorial in $\mathrm{cm}$ ), TSS\% (by a hand refractometer), total sugars and total acidity\% (as g tartaric acid/100ml juice) (A.O.A.C., 2000).

Statistical analysis was manually done and the treatment means were compared using New L.S.D. at 5\% according to method described by Mead et al. (1993).

\section{RESULTS AND DISCUSSION}

\section{Vegetative growth characteristics:}

Data in Table 2 clearly show that treating Prime seedless grapevines with chitosan at 50 to $800 \mathrm{ppm}$ significantly stimulated the six growth aspects namely main shoot length, number of leaves/shoot, leaf area, wood ripening coefficient, cane thickness and pruning wood weight relative to the check treatment. The promotion was in proportional to the increase in chitosan concentrations. Using chitosan at concentrations above $200 \mathrm{ppm}$ had no significant promotion on the six growth aspects when compared to $200 \mathrm{ppm}$. The maximum values were recorded on the vines that treated three times chitosan at $800 \mathrm{ppm}$. The lowest values were recorded on untreated vines. These results were true during both seasons.

\section{Leaf chemical composition:}

It is noticed from the data in Table 3 that chlorophylls a \& b, total carotenoids, $\mathrm{N}, \mathrm{P}, \mathrm{K}$ and $\mathrm{Mg}$ in the leaves were significantly affected by foliar application of chitosan at 50 to $800 \mathrm{ppm}$ compared to the control treatment. The promotion was correlated with increasing concentrations of chitosan at 50 to $200 \mathrm{ppm}$. However, using concentrations of chitosan above $200 \mathrm{ppm}$ failed to show significant promotion on these chemical components in comparison to applying chitosan at $200 \mathrm{ppm}$. The maximum values were recorded on the vines that received three sprays of chitosan at $800 \mathrm{ppm}$. The untreated vines produced the minimum values. Similar results were announced during both seasons. 


\begin{tabular}{|c|c|c|c|c|c|c|c|c|}
\hline \multirow{2}{*}{ 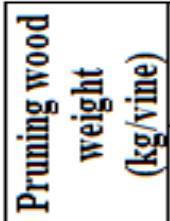 } & 웅 & $\stackrel{ }{-}$ & $\cong$ & $\stackrel{\sim}{\mathrm{i}}$ & $\stackrel{\Xi}{\sim}$ & $\approx$ & $\stackrel{\sim}{\sim}$ & $\overrightarrow{0}$ \\
\hline & 鱼 & $\Xi$ & $\stackrel{\circ}{-}$ & $\vec{r}$ & $\stackrel{\circ}{\sim}$ & $\stackrel{\circ}{\circ}$ & $\stackrel{\circ}{\circ}$ & "? \\
\hline \multirow{2}{*}{ 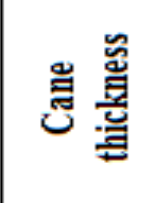 } & 웅 & よ゙ & $\stackrel{2}{2}$ & $\stackrel{9}{\equiv}$ & $\stackrel{\infty}{\beth}$ & $\stackrel{9}{3}$ & 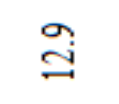 & $\vec{\sigma}$ \\
\hline & 总 & $\vec{a}$ & $\stackrel{\infty}{\infty}$ & 응 & $\stackrel{\Omega}{\Xi}$ & $\stackrel{\circ}{\stackrel{ }{\prime}}$ & $\underset{\mathrm{Z}}{ت}$ & $\stackrel{2}{\circ}$ \\
\hline \multirow{2}{*}{ 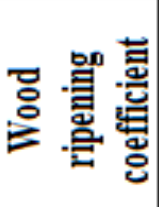 } & 응 & 志 & $\bar{\sigma}$ & $\stackrel{\infty}{\sigma}$ & $\begin{array}{l}\infty \\
\infty \\
0\end{array}$ & $\begin{array}{l}\infty \\
0 \\
0\end{array}$ & 同 & $\stackrel{5}{\circ}$ \\
\hline &  & : & $\bar{\sigma}$ & $\frac{9}{0}$ & $\stackrel{\text { ̊̊ }}{\circ}$ & 용 & $\vec{\sigma}$ & $\stackrel{2}{\circ}$ \\
\hline \multirow{2}{*}{ 壱芯 } & 응 & o & $\stackrel{a}{=}$ & ำ & $\stackrel{\circ}{\Xi}$ &  & $\stackrel{m}{\Xi}$ & $\stackrel{\square}{\square}$ \\
\hline & 曲 & 용 & 文 & $\begin{array}{l}0 \\
\text { +் }\end{array}$ & 을 & $\stackrel{m}{\varrho}$ & $\stackrel{\circ}{\circ}$ & 二 \\
\hline \multirow{2}{*}{ 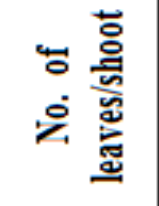 } & 을 & $\stackrel{\circ}{\stackrel{ }{\jmath}}$ & 일 & $\stackrel{ }{\Xi}$ & 옹 & 윰 & 융 & 요 \\
\hline & 옥 & $\stackrel{\circ}{\equiv}$ & $\stackrel{\circ}{\text { m }}$ & 임 & $\stackrel{\circ}{\infty}$ & $\stackrel{0}{\infty}$ & $\stackrel{\circ}{\infty}$ & $\stackrel{i}{i}$ \\
\hline \multirow{2}{*}{ 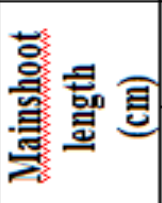 } & 음 & g & $\begin{array}{l}\text { 웅 } \\
\text { 응 }\end{array}$ & $\stackrel{g}{\varrho}$ & 兽 & $\stackrel{m}{\varrho}$ & 邑 & $\pi$ \\
\hline & 옥 & 용 & $\stackrel{2}{2}$ & 응 & $\stackrel{\circ}{\Xi}$ & 三 & $\stackrel{\text { త్ }}{\Xi}$ & 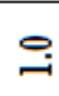 \\
\hline \multicolumn{2}{|l|}{$\begin{array}{l}\text { 岂 } \\
\text { 总 } \\
\text { 总 }\end{array}$} & 흘 & 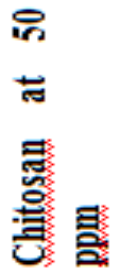 & 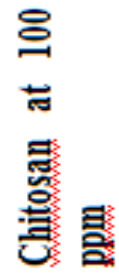 & 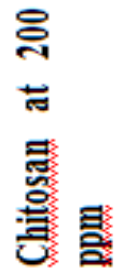 & 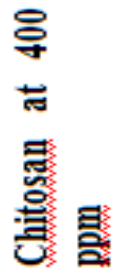 & 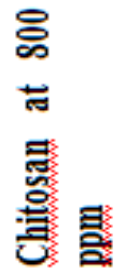 & 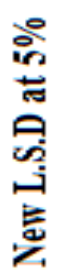 \\
\hline
\end{tabular}


ESRAA HUSSEIN

\begin{tabular}{|c|c|c|c|c|c|c|c|c|c|}
\hline 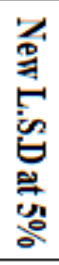 & 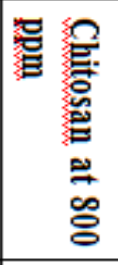 & 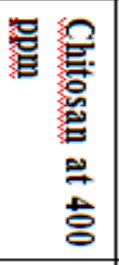 & 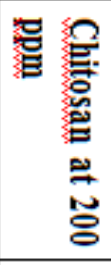 & 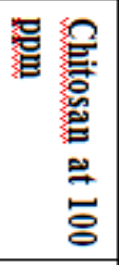 & 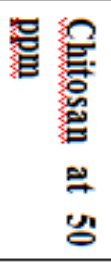 & 号 & & $\begin{array}{l}\text { 营 } \\
\text { 蒫 } \\
\text { 总 }\end{array}$ & \\
\hline ஜூ & in & $i$ & 8 & $\underset{\infty}{+\infty}$ & $\stackrel{\omega}{\sim}$ & w & 苍 & \multirow{2}{*}{ 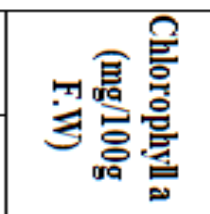 } & \\
\hline$\stackrel{\ominus}{\sim}$ & $\stackrel{\rightarrow}{\rightarrow}$ & i & in & ú & (o & $\tilde{\sigma}$ & 蒿 & & \\
\hline$\stackrel{\circ}{\circ}$ & $\begin{array}{l}N \\
\infty\end{array}$ & $\stackrel{\sim}{\sim}$ & $\tilde{a}$ & $\overrightarrow{0}$ & $\stackrel{\vec{\oplus}}{\oplus}$ & $\ddot{\circ}$ & 导 & \multirow{2}{*}{ 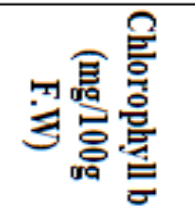 } & \\
\hline$\stackrel{8}{0}$ & $\sim$ & $\stackrel{N}{\sim}$ & $\stackrel{\sim}{\sim}$ & No & $\stackrel{\oplus}{\oplus}$ & 이 & 苔 & & \\
\hline$\stackrel{0}{i}$ & $\stackrel{N}{\oplus}$ & $\stackrel{N}{\oplus}$ & $N$ & ம) & $\overrightarrow{\mathrm{u}}$ & $\doteqdot$ & 导 & \multirow{2}{*}{ 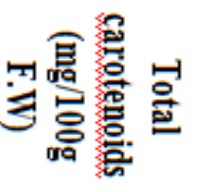 } & \\
\hline i & $\sim$ & $\sim$ & $\stackrel{\sim}{\leftarrow}$ & $\underset{\infty}{-}$ & $\stackrel{\bullet}{\oplus}$ & 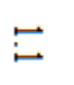 & 苍 & & \\
\hline 용 & 官 & $\ddot{\bullet}$ & $\vec{\circ}$ & $\underset{\nabla}{\sigma}$ & $\ddot{\circ}$ & $\underset{\mathrm{in}}{ }$ & 弚 & \multirow{2}{*}{ 。总 } & \\
\hline 용 & $\ddot{\circ}$ & $\vec{\circ}$ & $\stackrel{b}{\infty}$ & $\stackrel{\vec{\sigma}}{ }$ & $\underset{\perp}{\stackrel{D}{+}}$ & 官 & 关 & & \\
\hline 穴 & 은 & $\underset{\sim}{\stackrel{\circ}{+}}$ & $\stackrel{\circ}{\stackrel{\circ}{+}}$ & $\stackrel{\circ}{\stackrel{ }{\ominus}}$ & $\stackrel{\circ}{\ominus}$ & $\stackrel{\circ}{\stackrel{0}{\perp}}$ & 兑 & \multirow{2}{*}{$\therefore$ 占总 } & \\
\hline ஜํㅛ & 옥 & 응 & 酋 & 品 & $\stackrel{\circ}{\circ}$ & $\stackrel{\circ}{\bullet}$ & 总 & & \\
\hline$\stackrel{\circ}{\circ}$ & $\stackrel{\bullet}{\omega}$ & $\ddot{\omega}$ & $\ddot{v}$ & $\ddot{\oplus}$ &  & ஜ무 & 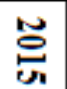 & \multirow{2}{*}{$\therefore \underset{0}{\stackrel{5}{心}}$} & \\
\hline 용 & $\ddot{\omega}$ & $\ddot{\omega}$ & $\underset{\sim}{\omega}$ & 芯 & $\underset{\varpi}{\varpi}$ & 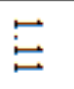 & 垥 & & \\
\hline 잉 & $\stackrel{\circ}{\circ}$ & $\begin{array}{l}\circ \\
0 \\
0\end{array}$ & 응 & $\begin{array}{l}\circ \\
\stackrel{2}{+}\end{array}$ & 웅 & 음 & 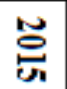 & \multirow{2}{*}{ 。点 } & \\
\hline 잉 & $\stackrel{\circ}{\sim}$ & $\stackrel{\circ}{\sim}$ & $\stackrel{ }{ }$ & $\stackrel{\circ}{\circ}$ & i̊ & 윽 & 关 & & \\
\hline
\end{tabular}




\section{Berry setting \%, yield and cluster weight:}

It is clear from the data in Table 4 that subjecting Prime seedless grapevines three times with chitosan at 50 to $800 \mathrm{ppm}$ significantly berry setting $\%$, improved yield expressed in weight and number of clusters/vine and cluster weight relative to the control treatment. The promotion was associated with increasing concentrations of chitosan. Using chitosan with concentrations above $200 \mathrm{ppm}$ had negligible promotion. Number of clusters/vine was significantly unaffected with varying concentrations of chitosan in the first seasons of study. From economical point view, using chitosan at $200 \mathrm{ppm}$ gave the best results with regard to yield. Under such promised treatment, yield per vine reached 11.7 and $14.9 \mathrm{~kg}$ while the yield of untreated vines reached 9.6 and $10.2 \mathrm{~kg}$ during both seasons, respectively. The percentage of increment on the yield due to using the previous promised treatment over the check treatment reached 21.9 and 46.1 during both seasons, respectively.

\section{Percentage of shot berries:}

As shown in Table 4, it was significantly reduced with using chitosan via leaves at 50 to $800 \mathrm{ppm}$ relative to the control treatment. There was a gradual reduction on such undesirable phenomena with increasing concentrations of chitosan from 50 to $800 \mathrm{ppm}$ no significant reduction on such parameter was observed when chitosan was applied at concentrations above $200 \mathrm{ppm}$ compared to $200 \mathrm{ppm}$ itself. The lowest valuewas recorded on the vines that treated with chitosan at $800 \mathrm{ppm}$. Treating the vines with chitosan at $0.0 \mathrm{ppm}$ gave the highest values. Similar trend was noticed during both seasons.

\section{Physical and chemical characteristics of the berries:}

It is clear from the data in Table 5 that treating Prime seedless grapevines with chitosan at 50 to $800 \mathrm{ppm}$ was significantly effective in improving berries quality in terms of increasing berry weight and dimensions (longitudinal and equatorial), TSS $\%$ and total sugars $\%$ and reducing titratable acidity\% over the check treatment. There was a progressive promotion on berries quality with increasing concentrations of chitosan. Significant differences on quality of berries were detected with increasing concentrations from 0.0 to $200 \mathrm{ppm}$. Using chitosan at concentrations above $200 \mathrm{ppm}$ had no significant promotion on quality parameters compared to applying chitosan at $200 \mathrm{ppm}$. The maximum berry weight and dimensions, TSS\% and total sugars $\%$ and the minimum titratable acidity\% were recorded on the vines that treating with chitosan at 





J. Product. \& Dev., 22(3),2017

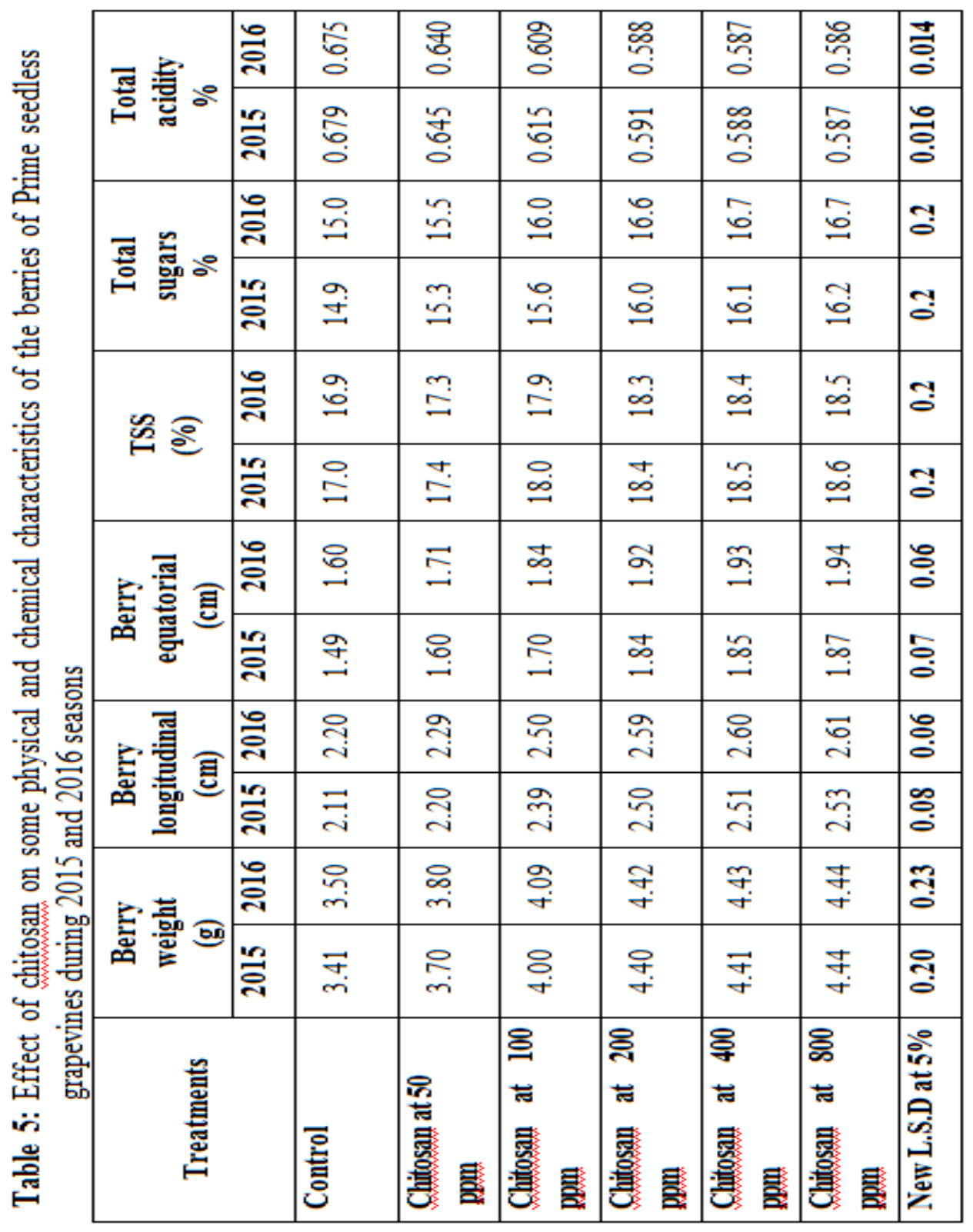


$800 \mathrm{ppm}$. Treating the vines with vehicle (water only) gave unfavorable effects on quality of the berries. These results were true during both seasons.

\section{DISCUSSION}

The previous positive action of chitosan on growth and fruiting of Prime seedless grapevines might be attributed to its essential effect on enhancing the tolerance of plants to biotic and abiotic stresses and plant metabolism as well as reducing transpiration and the formation of reactive oxygen species (ROS) and protecting the plants from aging (Park et al., 2004; Limpanuvech et al., 2008; Dzung et al., 2011; Mondal et al., 2012; Jabeen and Ahmad, 2013 and Pongprayaan et al., 2013).

The results are in harmony with those obtained by Imeri and Knoor, (1988); Gasen-Metithanis, (1996); Siripatrawan and Harte, (2010); Corradinin et al., (2010); Ghasemneznad et al., (2010); Abdel-Mawgoud et al., (2010); Abd Jabbar and Miamaj, (2012); Salachna and Zawadzinska, (2014) and Plainsirichai et al., (2015).

Conclusively, treating Prime Seedless grapevines grown under sandy soil condition three times with chitosan at $200 \mathrm{ppm}$ gave the best results with regard to yield and berries quality.

\section{REFERENCES}

Abdel- Mawgoud, A.M.R.; Tantawy, A.S.; El-Nemr, M.H. and Sassine, Y.N. (2010): Growth and yield responses of strawberry plants to chitosan application. European J. of Sci. Res., 39(1): 161-168.

Abd El- Jabbar, A. and Niamah, A.K. (2012): Effect of chitosan on apple juice quality. Inter. J. of agric. and Food Sci., 2(4): 153-157.

Ahmed, F.F. and Morsy, M.H. (1999): A new method for measuring leaf area in different fruit species. Minia J. of Agric. Res. \& Develop., 19: 97-105.

Al-Hetar, M. Y., Zainal Abidin, M. A.; Sariah, M. and WongM.Y. (2011): Antifungal activity of chitosan against Fusarium oxysporum f. sp. cubense. Journal of Appl. Polym. Science, 120(4): 2434-2439.

Association of Official Agricultural Chemists (2000): Official Method of Analysis (A.P.A.C.) $15^{\text {th }}$ Ed., Published by A.O.A.C. Washington, D.C.( U.S.A.) pp. 490-510.

Aranaz, I., Mengíbar, M., Harris, R., Paños, I., Miralles, B., Acosta, N., Galed, G. and Heras, Á. (2009). Functional characterization of chitin and chitosan. Biol., 3(2):203-230. 
Bittelli, M., Flury, M., Campbell, G.S. and Nichols, E.J. (2001). Reduction of transpiration through foliar application of chitosan. Agric. and Forest Meteorology, 107(3):167-175.

Balo, E.; Prilesszky, G.; Happ, I.; Kaholami, M, and Vega. L.(1988): Soil improvement and the use of leaf analysisfor forecasting nutrient requirements of grapes. Potash Review (Subject 9, $2^{\text {nd }}$ Suite, No. 61: $1-5)$.

Bouard, J. (1966): Recharches, physiologiques sur la vigen at en particulier sur laoudment des serments. Thesis Sci. Nat. Bardeux France, p.34.

Chibu, H. and Shibayama, H. (1999):Effects of chitosan applications on the early growth of several crops. Report of Kyushu Branch of the Crop Sci. Soc. of Japan, 65: 83-87.

Clark, M. F. and Adams, A. N. (1977): Characteristics of the microplate method of enzyme-linked immunosorbent assay for the detection of plant viruses. Gene. Virol. 34(3):475-483.

Cottenie,A.; Verloo, M.; Velghe, M. and Camerlynck, R. (1982): Chemical Analysis of Plant and Soil. Ghent, Belgium, Laboratory of Analytical and Agro-chemistry. State Univ. pp. 200-210.

Corradini, E., De Moura, M. R., and Mattoso, L. H. C. (2010): A preliminary study of the incorparation of NPK fertilizer into chitosan nanoparticles. Express Polymer Letters, 4(8): 509-515.

Devlieghere, F., Vermeulen, A.and Debevere, J. (2004): Chitosan: antimicrobial activity, interactions with food components and applicability as a coating on fruit and vegetables. Food microbiology, 21(6): 703-714.

Dias, A. M. A., Cortez, A. R., Barsan, M. M., Santos, J. B., Brett, C. M. A. and De Sousa, H. C. (2013): Development of greener multiresponsive chitosan biomaterials doped with biocompatible ammonium ionic liquids. ACS Sustainable Chem. Eng., 1(11): 14801492.

Dzung, N. A., Khanh, V. T. P. and Dzung, T. T. (2011). Research on impact of chitosan oligomers on biophysical characteristics, growth, development and drought resistance of coffee. Carbohydr. Polym., 84(2): 751-755.

El-Eleryan - Eman E.(2015):Effect of chitosan and green tea on the quality of Washington Navel orange during cold storage.Amer. J. of Plant Physiology 10 (1): 43-54.

Ghasemnezhad, M. and Shiri, M. A. (2010): Effect of chitosan coatings on some quality indices of apricot (Prunus armeniaca L.) during cold storage. Caspian J. of Env. Sci., 8(1): 25-33. 
Goosen-Mattheus, F.A. (1996): Applications of Chitan and Chitosan. CRC Press, 132-139. ISBN: 978-1-56676-449-0.

Hadwiger, L. A. (2013): Multiple effects of chitosan on plant systems: solid science or hype. Plant Sci.208:42-49.

Hiscox, A. and Isralstam, B. (1979): A method for the extraction of chlorophyll from leaf tissue without maceration. Can. J. Bot., 57: 1332 - 1334 .

Imeri, A. G., and Knorr, D. (1988): Effects of chitosan on yield and compositional data of carrot and apple juice. J. of Food Sci., 53(6): 1707-1709.

Jabeen, N. and Ahmad, R. (2013). The activity of antioxidant enzymes in response to salt stress in safflower (Carthamus tinctorius L.) and sunflower (Helianthus annuus L.) seedlings raised from seed treated with chitosan. J. Sci. Food Agric., 93(7):1699-1705.

Kamińska, M. (1991). Preparation and testing of antiserum to freesia mosaic virus (FMV). Phytopath. Polonica, VII: 5-7.

Kulikov, S. N., Chirkov, S. N., Il'ina, A. V., Lopatin, S. A. and Varlamov, V. P. (2006). Effect of the molecular weight of chitosan on its antiviral activity in plants. Appl. Biochem. Micro., 42(2):200203.

Lane, J. H. and Eynon, L. (1965): Determination Of Reducing Sugars By Means Of Fehlings Solutions With Methylene Blue As Indicator. A. O. A. C. Washington D. C., U.S.A.

Li, H. and Yu, T. (2001). Effect of chitosan on incidence of brown rot, quality and physiological attributes of postharvest peach fruit. Journal of the Science of Food and Agric., 81(2): 269-274.

Li, M., Chen, X., Liu, J., Zhang, W. and Tang, X. (2011). Molecular weight-dependent antifungal activity and action mode of chitosan against Fulvia fulva (cooke) ciffrri. J. Appl. Polym. Sci., 119(6):31273135 .

Limpanavech, P., Chaiyasuta, S., Vongpromek, R., Pichyangkura, R., Khunwasi, C., Chadchawan, S., Lotrakul, P., Bunjongrat, R., Chaidee, A. and Bangyeekhun, T., (2008): Chitosan effects on floral production, gene expression, and anatomical changes in the Dendrobium orchid. Sci. Hortic., 116(1): 65-72.

Lizárraga-Paulín, E. G., Torres-Pacheco, I., Moreno-Martínez, E., \& Miranda-Castro, S. P. (2011). Chitosan application in maize (Zea mays) to counteract the effects of abiotic stress at seedling level. Afr. J. Biotechnol., 10(3): 6439-6446. 
Mead, R.; Currnow, R. N. and Harted, A. M. (1993): Statistical Biology. 2"d Ed. Methods in Agriculture and Experimental and Hall, London pp. 10-20.

Mondal, M. M. A., Malek, M. A., Puteh, A. B., Ismail, M. R., Ashrafuzzaman, M., \& Naher, L. (2012): Effect of foliar application of chitosan on growth and yield in okra. Aust. J. Crop Science, 6(5):918-921.

Nguyen-Van, S., Minh, H.D. and Anh, D.N., 2013. Study on chitosan nanoparticles on biophysical characteristics and growth of Robusta coffee in green house. Biocatal. Agric. Biotechnol, 2(4): 289-294.

Park, P. J., Je, J. Y. and Kim, S. K. (2004): Free radical scavenging activities of differently deacetylated chitosans using an ESR spectrometer. Carbohydrate Polymers, 55(1): 17-22.

Plainsirichai, M., Leelaphatthanapanich, S. and Wongsachai, N. (2014). Effect of chitosan on the quality of rose apples (Syzygium agueum Alston) cv. Tabtim Chan stored at an ambient temperature. APCBEE Procedia, 8: 317-322.

Pongprayoon, W., Roytrakul, S., Pichayangkura, R. and Chadchawan, S. (2013). The role of hydrogen peroxide in chitosan-induced resistance to osmotic stress in rice (Oryza sativa L.). Plant Growth Regul., 70(2):159-173.

Salachna, P. and Zawadzińska, A. (2014). Effect of chitosan on plant growth, flowering and corms yield of potted freesia. J. of Ecological Engineering, 15(3): 97-102.

Siripatrawan, U. and Harte, B. R. (2010). Physical properties and antioxidant activity of an active film from chitosan incorporated with green tea extract. Food Hydrocolloids, 24(8):770-775. 


\title{
سلوك كرمات العنب البرايم سيدلس النامية فى التربة الرملية لرش الثنتوسان
}

\author{
إسراء محمود السيا حسين \\ قسم البساتين- كلية الزر اعة- جامعة أسوانـ مصر البين
}



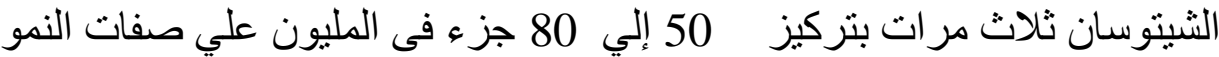

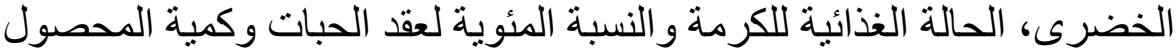

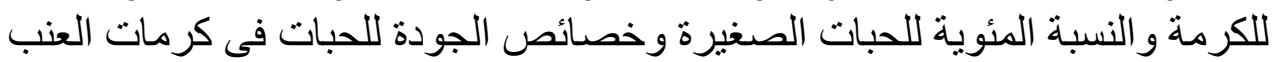
البر ايم سيدلس النامى فى النربة الرملية.



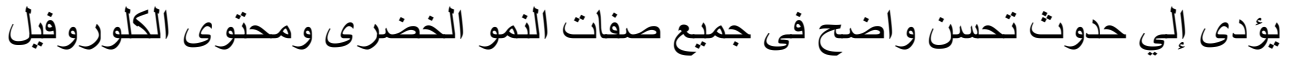

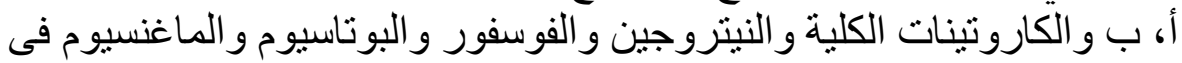



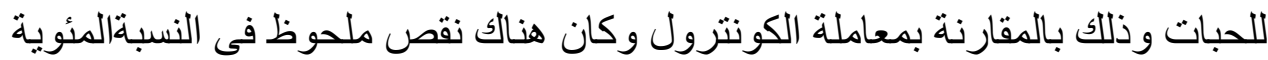
للحبات الصغيرة في معاملات الثيتوسان.



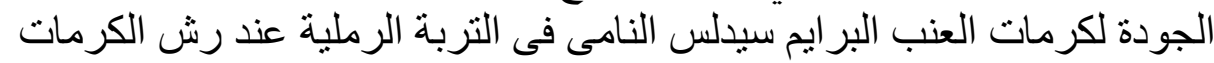

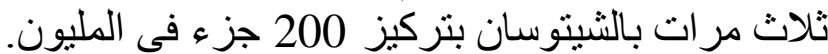
الكلمات الدالة : الثيتوسان-العنب البرايم سيدلس - كمية المحصول - خصائص

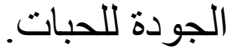


